\title{
Morphometric Analysis of Human Second Cervical Vertebrae (Axis)
}

Teo EC ${ }^{1 *}$, Haiblikova $\mathbf{S}^{2}$, Winkelstein $\mathrm{B}^{3}$, Welch $\mathbf{W}^{3}$, Holsgrove $\mathrm{T}^{4}$ and Cazzola $\mathrm{D}^{5}$

${ }^{1}$ School of Mechanical and Aerospace Engineering, College of Engineering, Nanyang Technological University, Singapore

${ }^{2}$ Department of Biomechanics and Medical Instruments, Czech Technical University in Prague, Czech Republic

${ }^{3}$ Department of Bioengineering, School of Engineering and Applied Sciences, University of Pennsylvania, USA

${ }^{4}$ Department of Engineering, University of Exeter, UK

${ }^{5}$ Department of Health, University of Bath, UK

${ }^{*}$ Corresponding author: E.C. Teo, School of Mechanical and Aerospace Engineering, College of Engineering, Nanyang Technological University, Singapore, Tel: +65 67905529; Fax: +65 67924062; E-mail: mecteo@ntu.edu.sg

Rec Date: Dec 08, 2017; Acc Date: Dec 12, 2017; Pub Date: Dec 16, 2017

Copyright: (C) 2017 Teo EC, et al. This is an open-access article distributed under the terms of the Creative Commons Attribution License, which permits unrestricted use, distribution, and reproduction in any medium, provided the original author and source are credited.

\section{Abstract}

Possessing an odontoid process and unique superior articular facets, the axis vertebra morphometry significantly differs from morphometry of other cervical vertebrae. The fractures of axis, especially its dens, are very common and surgeries highly risky. Knowledge of the axis dimensions is essential not only for preclinical studies, diagnosis of spinal cord diseases, planning of the surgeries but also for correct selection and insertion of surgical instruments or vertebral implants design. Many quantitative studies of the second cervical vertebra have been performed, yet still lacking the area parameters determination and precision of three-dimension in vivo measurement. Vertebral dimensions are reported to vary among populations, although there are very little studies examining Caucasian specimen.

This study aims to provide three-dimensional in vivo morphometric analysis of the axis vertebra as well as comparison to the previous studies. The clinically relevant vertebral dimensions were measured on the threedimensional model reconstruction of CT scans providing high accuracy. Five human second cervical vertebrae were investigated (Caucasian males) and linear, area and angular dimensions were measured.

The data on vertebral body dimensions were best fitting Doherty and Naderi measurement. The vertebra body anterior height was established to be $26.2 \mathrm{~mm}$ and the posterior height $21.4 \mathrm{~mm}$. The dens parameters were similar to those presented by Doherty. Doherty also reported large variation in the dens sagittal angle which was observed in the present study as well. The dens height was determined to be $17.8 \mathrm{~mm}$ which is significantly greater compared to the previous studies. The smallest height among specimens was reported to be $17.0 \mathrm{~mm}$. The smallest anteroposterior or transverse diameter of the dens measured was the upper depth, $9.4 \mathrm{~mm}$. The smallest and biggest areas of dens were measured to be $79.0 \mathrm{~mm}^{2}$ and $121.6 \mathrm{~mm}^{2}$. The superior articular facet area with mean value $211.2 \mathrm{~mm}^{2}$ was observed to be significantly bigger than the inferior area, $141.2 \mathrm{~mm}^{2}$. The mean sagittal angle of the inferior facet area was assessed to be $42.1^{\circ}$ and the mean frontal angle of the superior articular facet $69.3^{\circ}$. The parameters of articular facets measured by $\mathrm{Xu}$ correspond to the present study. Due to the vertebral body enlargement in the inferior part of vertebra, the spinal canal superior depth,18.0 mm, was observed to be bigger than its inferior depth, $16.2 \mathrm{~mm}$. In case of the spinal canal depth, Sengul measured values considerably greater than other studies. However, Singla, Gosavi and Xu presented the parameters very similar to the present study. Spinal canal width was measured to be $24.4 \mathrm{~mm}$ supporting the measurement done by Sengul which is $24.7 \mathrm{~mm}$.

The measured vertebral dimensions can be used either for development of instrumentation, preclinical planning of surgeries, implant design or as the reference values for evaluation and diagnosis of various clinical conditions.

Keywords: Cervical vertebrae; Spinal canal; Odontoidectomy; Caucasian males

\section{Introduction}

The axis vertebra features an atypical shape and both its anatomical and biomechanical properties are unique. Diseases of the spinal column at cervical and lumbar region are among the most frequent syndromes [1]. It is also reported that the fractures of the dens axis account for nearly the third of cervical vertebrae fractures $[2,3]$. However, surgeries in this region are highly risky for possible damage to aorta or other adjacent vital structures [4-6]. Thus, the dimensions of instrumentations and their insertion need to respect anatomical features of the vertebra. Not only for treatment of vertebral diseases and instabilities, but also for diagnoses, the knowledge of the exact vertebral dimensions is crucial. As the ethnical differences in the vertebral dimensions has been reported, it is also necessary to distinguish the patient origin [7-9]. Regarding all these statements, it is obvious that wide range of precise and clinically important parameters corresponding to the specimen ethnical origin is necessary.

Due to its frequent fractures, the main interest of previous studies was the odontoid process and the vertebral body [10-13]. The parameters such as dens axis high, width, depth and vertebral body height were examined as they are important factors for odontoid screw 
fixation, transoral odontoidectomy, anterior and posterior stabilization of odontoid process. Although, the area of dens, which seems to be more relevant for screw design as well as stress distribution, is yet to be determined. Other studies focused more on the spinal canal parameters which play an important role in stenosis and itraspinal tumours diagnosis [14-16]. Some of the researches devoted themselves to measure the pedicle parameters for transpedicular crew fixation [8,17-22]. The previous studies obtained morphometric parameters either from CT scans or radiographs $[10,16,17,23]$ or by direct measurement performed on cadavers [15,18,24-27].

This study aims to provide clinically relevant parameters of second cervical vertebra. Twenty-seven linear, area and angular parameters are measured using a novel tree-dimensional in vivo technique of morphometric analysis. For further comparison purposes, the measured parameters definition follows the previous studies. The reference study defining most of the parameters is the study done by $\mathrm{Xu}$ [18], then Sengul and Singla [15,27]. The measured vertebral dimensions can be used either for development of instrumentation, preclinical planning of surgeries, implant design or as the reference values for evaluation and diagnosis of various clinical conditions.

\section{Materials and Methods}

Study included five specimens with no evidence of spinal disease (Caucasian males, average age 61 years). CT scans of the axis vertebra were provided by The Shape Spine Biomechanics and Spine Pain Research Lab, Uni of Pennsylvania, US. The images were obtained using CT Scanner [Siemens Somatom Definition Flash] with $0.6 \mathrm{~mm}$ slice thickness and $512 \times 512$ matrix. The morphometric analysis of vertebra was focused on the odontoid process, vertebral body, articular facets and vertebral canal.

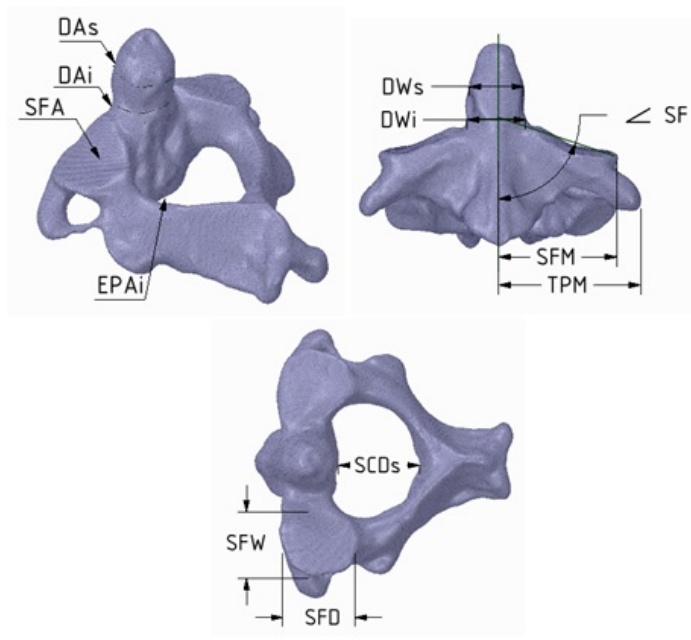

Figure 1: Isometric, posterior and superior view of the axis.

The method of the model reconstruction was followed as described in the previous study [28]. The three-dimensional model was reconstructed from CT images using 3D image data processing software ScanIP Academic, [Synopsys Inc.]. The recursive gaussian filter for model smoothening was applied with sigma 0.8 in all axes. The three-dimensional model was subsequently imported into ANSYS
SpaceClaim where the vertebra orientation and all the measurements were performed.

\begin{tabular}{|c|c|c|}
\hline \multicolumn{3}{|l|}{ Body } \\
\hline Vertebral body depth & VBD & $\begin{array}{l}\text { The widest AP dimension of the inferior } \\
\text { end-plate of the vertebral body [18]. }\end{array}$ \\
\hline Vertebral body width & VBW & $\begin{array}{l}\text { The widest transverse dimension of the } \\
\text { inferior end-plate of the vertebral body } \\
\text { [18]. }\end{array}$ \\
\hline Vertebral body area & VBA & $\begin{array}{l}\text { The area of the inferior end-plate of the } \\
\text { vertebral body. }\end{array}$ \\
\hline $\begin{array}{l}\text { Vertebral body anterior } \\
\text { height }\end{array}$ & VBHa & $\begin{array}{l}\text { From the anterior inferior edge to the } \\
\text { superior border, defined by superior line } \\
\text { of the superior articular facet; measured } \\
\text { in the anterior midline [18]. }\end{array}$ \\
\hline $\begin{array}{l}\text { Vertebral body posterior } \\
\text { height }\end{array}$ & VBHp & $\begin{array}{l}\text { Vertically in the posterior midline of the } \\
\text { vertebral body from the posterior } \\
\text { inferior edge to the superior border [18]. }\end{array}$ \\
\hline End-plate lip height & & $\begin{array}{l}\text { The difference between anterior and } \\
\text { posterior vertebral body height [24]. }\end{array}$ \\
\hline \multicolumn{3}{|l|}{ Dens } \\
\hline Dens superior width & DWs & $\begin{array}{l}\text { The transverse diameter of the dens } \\
\text { measured on frontal plane at the level } \\
\text { of upper curvature. }\end{array}$ \\
\hline Dens inferior width & DWi & $\begin{array}{l}\text { The transverse diameter of the dens } \\
\text { measured on frontal plane at root of the } \\
\text { dens. }\end{array}$ \\
\hline Dens superior depth & DDs & $\begin{array}{l}\text { Antero-posterior diameter at the level of } \\
\text { DAWs. }\end{array}$ \\
\hline Den inferior depth & $\mathrm{DDi}$ & $\begin{array}{l}\text { Antero-posterior diameter at the level of } \\
\text { DAWi. }\end{array}$ \\
\hline Dens area superior & DAs & $\begin{array}{l}\text { Area of the dens axis at the level of } \\
\text { DAWs. }\end{array}$ \\
\hline Dens area inferior & DAi & $\begin{array}{l}\text { Area of the dens axis at the level of } \\
\text { DAWi. }\end{array}$ \\
\hline Dens height & $\mathrm{DH}$ & $\begin{array}{l}\text { From superior-most point of the dens to } \\
\text { the superior line of the superior articular } \\
\text { facet [18]. }\end{array}$ \\
\hline Dens vertical angle & $<\mathrm{DV}$ & $\begin{array}{l}\text { Between the axis of the dens and the } \\
\text { inferior surface of the vertebral body } \\
\text { [18]. }\end{array}$ \\
\hline Dens sagittal angle & $<\mathrm{DS}$ & $\begin{array}{l}\text { Sagittal angle of the dens axis with the } \\
\text { respect to the frontal plane [15]. }\end{array}$ \\
\hline \multicolumn{3}{|c|}{ Facet area and transverse process } \\
\hline $\begin{array}{l}\text { Superior articular facet to } \\
\text { the midline }\end{array}$ & SFM & $\begin{array}{l}\text { The most lateral edge of left/right } \\
\text { superior articular facet to the midline } \\
\text { [27]. }\end{array}$ \\
\hline $\begin{array}{l}\text { Transverse process to the } \\
\text { midline }\end{array}$ & TPM & $\begin{array}{l}\text { From the most lateral point of left/right } \\
\text { transverse process to the midline [27]. }\end{array}$ \\
\hline $\begin{array}{l}\text { Superior articular facet } \\
\text { depth }\end{array}$ & SFD & $\begin{array}{l}\text { The maximum antero-posterior } \\
\text { dimension of the left/right superior } \\
\text { articular facet [18]. }\end{array}$ \\
\hline Inferior articular facet depth & IFD & $\begin{array}{l}\text { The maximum antero-posterior } \\
\text { dimension of the left/right superior } \\
\text { articular facet [18]. }\end{array}$ \\
\hline
\end{tabular}




\begin{tabular}{|l|l|l|}
\hline Superior articular facet width & SFW & $\begin{array}{l}\text { The maximum transverse dimension of } \\
\text { the left/right superior articular facet [18]. }\end{array}$ \\
\hline Inferior articular facet width & IFW & $\begin{array}{l}\text { The maximum transverse dimension of } \\
\text { the left/right superior articular facet [18]. }\end{array}$ \\
\hline Superior articular facet area & SFA & $\begin{array}{l}\text { Area of left/right superior articular facet } \\
\text { measured on the plane parallel to the } \\
\text { facet surface. }\end{array}$ \\
\hline Inferior articular facet area & IFA & $\begin{array}{l}\text { Area of left/right inferior articular facet } \\
\text { measured on the plane parallel to the } \\
\text { facet surface. }\end{array}$ \\
\hline $\begin{array}{l}\text { Superior articular facet } \\
\text { angle }\end{array}$ & $<$ SF & $\begin{array}{l}\text { Frontal angle of left/right superior } \\
\text { articular facet with respect to the } \\
\text { sagittal plane [18]. }\end{array}$ \\
\hline Inferior articular facet angle & $<$ LF & $\begin{array}{l}\text { Sagittal angle of left/right inferior } \\
\text { articular facet surface with respect to } \\
\text { the transverse plane. }\end{array}$ \\
\hline
\end{tabular}

\section{Spinal canal}

\begin{tabular}{|l|l|l|}
\hline Spinal canal width & SCW & $\begin{array}{l}\text { The maximum transverse diameter of } \\
\text { spinal canal [18]. }\end{array}$ \\
\hline Spinal canal superior depth & SCDs & $\begin{array}{l}\text { The maximum AP diameter of the } \\
\text { spinal canal measured at the superior } \\
\text { inlet of the canal [18]. }\end{array}$ \\
\hline Spinal canal inferior depth & SCDi & $\begin{array}{l}\text { The maximum AP diameter of the } \\
\text { spinal canal measured at the inferior } \\
\text { outlet of the canal [18]. }\end{array}$
\end{tabular}

Table 1: The definition of measured parameters.

Each vertebra was orientated prior to the measurement to follow the definitions of parameters from previous studies. For coordinate system definition, two planes were established. The first vertical plane was defined by three points; the point in the axis of dens on its anterior surface, in the middle of antero-inferior edge of the vertebral body and in the middle of the tip of spinous process.

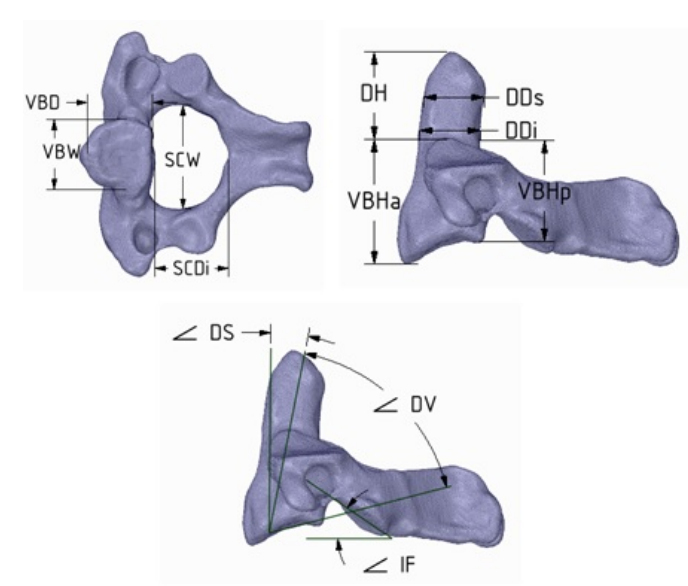

Figure 2: Inferior and lateral views of the axis.

The horizontal plane was defined by the three lowest points of the vertebra; one belonging to the inferior edge of the vertebral body, and other two situated either on the inferior articular facets or two ends of spinous process.
The vertebral orientation was followed by measurement. Each specimen was examined by one researcher obtaining eighteen linear, five area and four angular parameters. The exact definition of parameters is provided in Table 1 supported by graphical interpretation shown in Figures 1 and 2.

As a reference study for definition of paramaters served the study done by $\mathrm{Xu}$ [18], in case of some parameters missing, studies by Doherty, Sengul and Singla were followed [15,24,27].

\section{Results and Discussion}

Eighteen linear, five areas and four angular parameters were measured. Based on five investigated specimens, mean value, range and standard deviations were calculated. Table 1 summarizes all measured parameters for each specimen. The results were then compared to the previous studies [11,15,18,24-27].

On the vertebral body, anterior and posterior height as well as inferior end-plate dimensions were investigated. Parameters of the inferior end-plate included width, depth and area. Vertebral body data is provided in Table 2 .

\begin{tabular}{|l|l|l|l|l|l|}
\hline $\begin{array}{l}\text { Vertebral } \\
\text { Body }\end{array}$ & $\begin{array}{l}\text { Vertebral } \\
\text { body } \\
\text { depth }\end{array}$ & $\begin{array}{l}\text { Vertebral } \\
\text { body } \\
\text { width }\end{array}$ & $\begin{array}{l}\text { Vertebral } \\
\text { body } \\
\text { inferior } \\
\text { area }\end{array}$ & $\begin{array}{l}\text { Vertebral } \\
\text { body } \\
\text { anterior } \\
\text { height }\end{array}$ & $\begin{array}{l}\text { Vertebral } \\
\text { body } \\
\text { posterior } \\
\text { height }\end{array}$ \\
\hline VBL & VBW & VBAi & VBHa & VBHp \\
\hline Mean & 17.4 & 18.2 & 243.7 & 26.2 & 21.4 \\
\hline Maximum & 18.8 & 19.4 & 288 & 28 & 0.9 \\
\hline Minimum & 16.4 & 16.2 & 203 & 24.2 & 20 \\
\hline
\end{tabular}

Table 2: Measured dimensions of the vertebral body.

Vertebral body anterior height is in all cases bigger than posterior height (Figure 3), due to the vertebral wedging. Figure 3 also compares the inferior end-plate width and depth. Although the width is mostly bigger than the depth, values do not differ significantly and for specimen 2 and 3 they are almost the same.

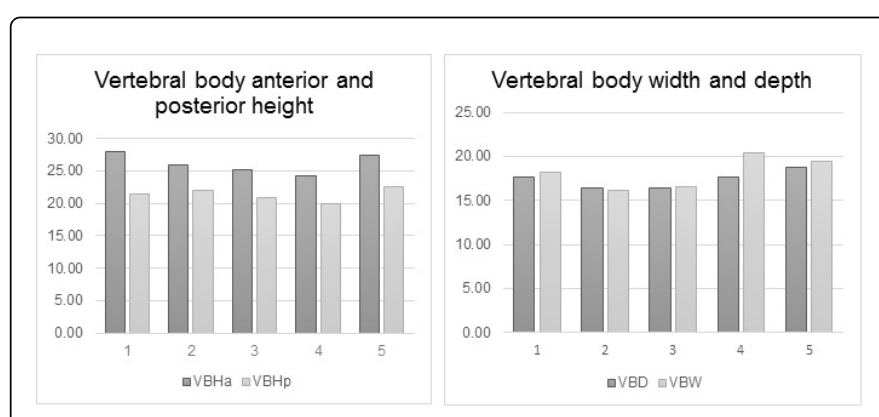

Figure 3: Measured data of vertebral body anterior and posterior height, width and depth for five specimens.

Vertebral body measurement including vertebral body length, width, anterior and posterior height was previously performed by Gosavi [26], Singla [27], Naderi [11], Xu [18] and Dohery [24]. In Figure 4 , the comparison to the present study is shown. For the 
Citation: Teo EC, Haiblikova S, Winkelstein B, Welch W, Holsgrove T, et al. (2017) Morphometric Analysis of Human Second Cervical Vertebrae (Axis). J Spine 6: 399. doi:10.4172/2165-7939.1000399

Page 4 of 7

comparison purposes, only mean value and standard deviation of parameters from the present study is taken into consideration. The results of the present study are the most resemble to the measurement done by Naderi and Doherty. Unlike the values of the depth and width which seems to be rather similar, the anterior and posterior height varies significantly. This can be due to the inaccurate definition of the line of superior border separating the body from the dens.

\begin{tabular}{|l|l|l|l|l|l|l|l|l|l|}
\hline Dens & $\begin{array}{l}\text { Dens } \\
\text { superior } \\
\text { width }\end{array}$ & $\begin{array}{l}\text { Dens inferior } \\
\text { width }\end{array}$ & $\begin{array}{l}\text { Dens } \\
\text { superior } \\
\text { depth }\end{array}$ & $\begin{array}{l}\text { Dens inferior } \\
\text { depth }\end{array}$ & $\begin{array}{l}\text { Dens superior } \\
\text { area }\end{array}$ & $\begin{array}{l}\text { Dens inferior } \\
\text { area }\end{array}$ & Dens height & $\begin{array}{l}\text { Dens vertical } \\
\text { angle }\end{array}$ & $\begin{array}{l}\text { Dens } \\
\text { sagittal } \\
\text { angle }\end{array}$ \\
\hline Mean & 11.5 & DWi & DDs & DDi & DAs & DAi & DH & DV & DS \\
\hline SD & 0.8 & 0.8 & 11.2 & 12.4 & 9.9 & 111.5 & 89.4 & 17.8 & 59.7 \\
\hline Maximum & 12.4 & 12.6 & 13.8 & 13.4 & 126.9 & 121.6 & 19.8 & 12.7 & 78.1 \\
\hline Minimum & 10.0 & 10.4 & 9.4 & 9.9 & 79.0 & 89.4 & 17.0 & 19.0 & 48.1 \\
\hline
\end{tabular}

Table 3: Measured parameters of the dens.

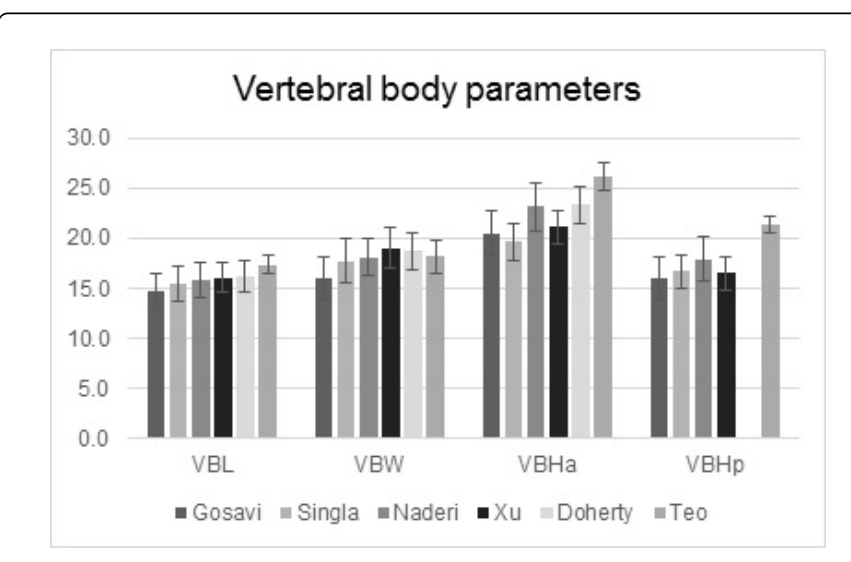

Figure 4: The comparison of vertebral body parameters to the previous studies.

The definition of dens parameters was complicated as the features of shape described in previous studies were not observed. $\mathrm{Xu}$ and Doherty measured two transverse parameters of the dens [18,24]; maximum width located at the upper part of the dens and minimum width located at the dens root. However, for the investigated specimens, the width of the dens at the upper curvature was sometimes smaller than the one measured at its root (Figure 1). The widths are thus called superior and inferior. The dens depth and cross-sectional area were then assessed at the level of previous measurement of widths. Table 3 shows the results of the measurement.

The smallest antero-posterior or transverse diameter of the dens was measured $9.4 \mathrm{~mm}$ as the upper depth of the dens. Smallest and biggest areas of dens axis were measured to be $79.0 \mathrm{~mm}^{2}$ and $121.6 \mathrm{~mm}^{2}$. The measured values of depth and width of the dens are compared to studies done by $\mathrm{Xu}$ and Doherty in Figure 5 . The results of the present study are more similar to Doherty's values. The comparison of high of dens is shown in Figure 5.

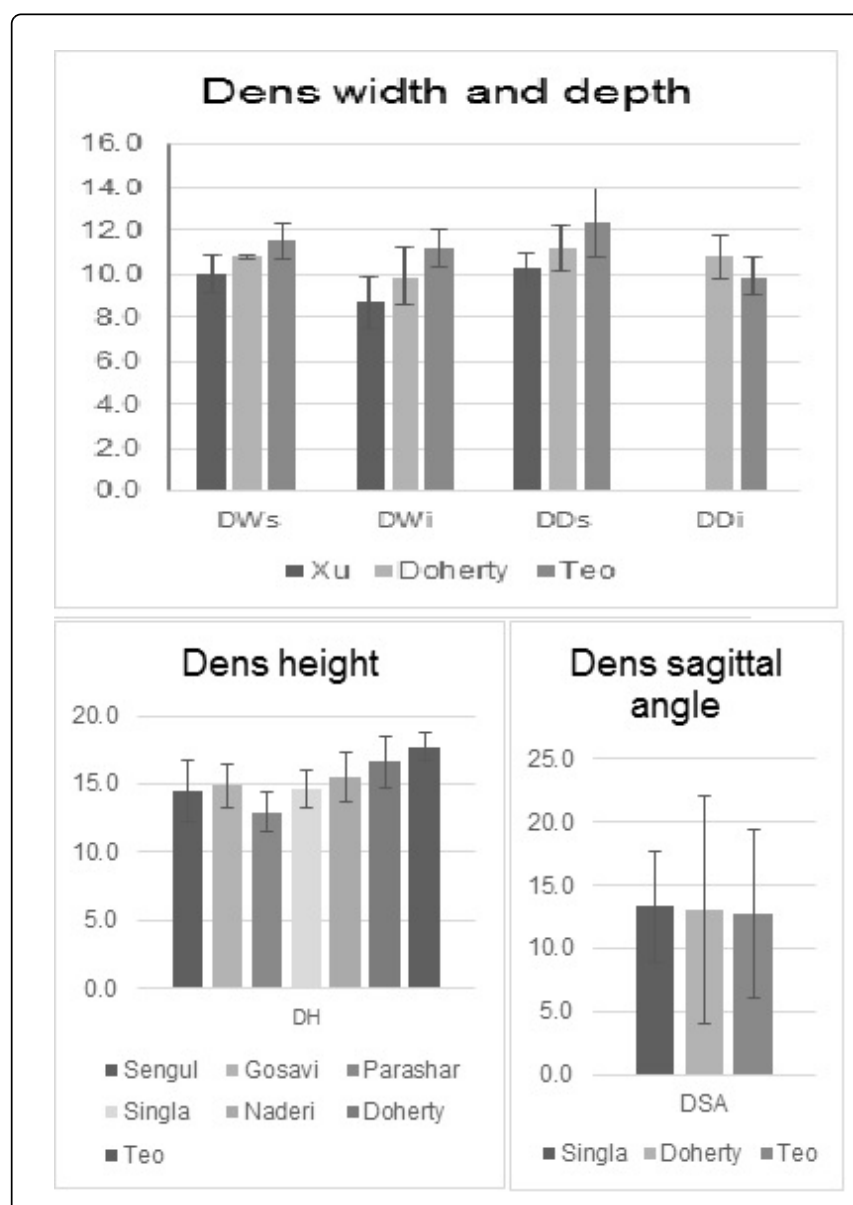

Figure 5: The comparison of the dens width, depth, heigh and sagittal angle to the previous studies.

The result of present study follows the Doherty's results. Dens axis high was determined to be $17.8 \mathrm{~mm}$ which is significantly greater compared to the previous studies. The smallest height among specimens was reported to be $17.0 \mathrm{~mm}$. There is a significant difference between the specimens in dens axis vertical angle as well as sagittal 
Page 5 of 7

angle represented by large standard deviation (Table 3 ). The large variation in sagittal angle of dens has already been reported by Doherty with values ranging from $-2^{\circ}$ to $42^{\circ}$. However, when compared to the study performed by Doherty and Singla, mean values of dens axis sagittal angle are very similar (Teo $12.7^{\circ}$, Doherty $13.0^{\circ}$ and Singla $13 \cdot 3^{\circ}$ ).
Superior and inferior articular facet areas were assessed for five linear, two area and two angular parameters. Linear parameters consist of width and depth of superior and inferior facet and the distance of the most lateral end of superior facet to the midline. The results are shown in Tables 4 and 5.

\begin{tabular}{|c|c|c|c|c|c|c|c|c|c|c|c|c|c|c|}
\hline \multirow{3}{*}{$\begin{array}{l}\text { Superior } \\
\text { articular } \\
\text { facet }\end{array}$} & \multicolumn{2}{|c|}{$\begin{array}{l}\text { Superior articular } \\
\text { facet to the midline }\end{array}$} & \multicolumn{3}{|c|}{ Superior articular facet depth } & \multicolumn{3}{|c|}{ Superior articular facet width } & \multicolumn{3}{|c|}{$\begin{array}{l}\text { Superior articular facet } \\
\text { area }\end{array}$} & \multicolumn{3}{|c|}{$\begin{array}{l}\text { Superior articular } \\
\text { facet angle }\end{array}$} \\
\hline & \multicolumn{2}{|l|}{ SFM } & \multicolumn{3}{|l|}{ SFD } & \multicolumn{3}{|l|}{ SFW } & \multicolumn{3}{|l|}{ SFA } & \multicolumn{3}{|l|}{ SF } \\
\hline & $\mathrm{R}$ & $\mathrm{L}$ & $\mathrm{R}$ & $\mathrm{L}$ & A & $\mathrm{R}$ & $\mathrm{L}$ & A & $\mathrm{R}$ & L & $A$ & $\mathrm{R}$ & $\mathrm{L}$ & $A$ \\
\hline Mean & 24.5 & 25.0 & 16.5 & 16.8 & 16.7 & 17.2 & 16.3 & 16.7 & 212.7 & 209.6 & 211.2 & 69.1 & 69.5 & 69.3 \\
\hline SD & 1.5 & 0.8 & 1.9 & 1.4 & 1.6 & 1.0 & 1.8 & 1.2 & 29.0 & 34.5 & 31.7 & 0.9 & 3.9 & 2.3 \\
\hline Maximum & 26.0 & 26.0 & 18.2 & 18.6 & 18.1 & 18.2 & 18.6 & 17.6 & 249.6 & 256.7 & 240.7 & 69.9 & 74.9 & 72.4 \\
\hline Minimum & 21.6 & 24.0 & 13.0 & 14.4 & 13.7 & 15.4 & 13.6 & 14.5 & 162.4 & 154.1 & 158.2 & 67.5 & 65.0 & 66.3 \\
\hline
\end{tabular}

Table 4: Measured parameters of the superior articular facet.

Unlike other studies, width and depth measurement of the facets was performed in horizontal or vertical direction as defined by $\mathrm{Xu}$
[18]. Areas of superior and inferior facet was estimated by outlining the facet area edge on the plane parallel to the surface of the facet.

\begin{tabular}{|c|c|c|c|c|c|c|c|c|c|c|c|c|}
\hline \multirow{3}{*}{$\begin{array}{l}\text { Inferior } \\
\text { facet } \\
\text { transverse } \\
\text { process }\end{array}$} & \multirow{2}{*}{\multicolumn{2}{|c|}{$\begin{array}{l}\text { Transverse process } \\
\text { to the midline }\end{array}$}} & \multirow{2}{*}{\multicolumn{2}{|c|}{$\begin{array}{l}\text { Inferior articular facet } \\
\text { depth }\end{array}$}} & \multicolumn{2}{|c|}{$\begin{array}{l}\text { Inferior articular facet } \\
\text { width }\end{array}$} & \multicolumn{3}{|c|}{ Inferior articular facet area } & \multicolumn{3}{|c|}{ Inferior articular facet angle } \\
\hline & & & & & IFW & & IFA & & & IF & & \\
\hline & $\mathrm{R}$ & $L$ & $\mathrm{R}$ & $\mathrm{L}$ & $\mathrm{R}$ & $\mathrm{L}$ & $\mathrm{R}$ & $\mathrm{L}$ & $A$ & $\mathrm{R}$ & $\mathrm{L}$ & $A$ \\
\hline Mean & 29.8 & 32.4 & 14.9 & 15.0 & 12.5 & 13.1 & 140.2 & 142.1 & 141.2 & 42.4 & 41.8 & 42.1 \\
\hline SD & 1.0 & 2.2 & 2.4 & 0.8 & 2.4 & 1.9 & 35.6 & 25.9 & 30.7 & 7.7 & 4.8 & 5.72 \\
\hline Maximum & 31.8 & 35.2 & 18.8 & 15.8 & 15.6 & 15.6 & 179.4 & 164.8 & 171.2 & 51.4 & 47.6 & 33.3 \\
\hline Minimum & 29.2 & 30.2 & 11.4 & 13.6 & 8.6 & 9.8 & 78.2 & 93.2 & 85.7 & 32.3 & 34.3 & 48.6 \\
\hline
\end{tabular}

Table 5: Measured parameters of the inferior facet area.

The results showed that superior facet area with mean value 211.2 $\mathrm{mm}^{2}$ is significantly larger than inferior facet area, $141.2 \mathrm{~mm}^{2}$ (Figure 6). The comparison of superior facet width and depth to the study done by $\mathrm{Xu}$ is shown in Figure 6. The results of the present study are slightly smaller than those measured by Xu. It is most likely due to the different technique of measurement. In the present study, only the surface of the facet areas was taken into consideration by estimation of facet edge, whereas $\mathrm{Xu}$ measured the parameters by caliper thus establishing the parameter from the edge of the articular process. The superior facet angle with respect to the sagittal plane was similar for all the specimens ranging between $65.0^{\circ}$ and $74.9^{\circ}$ with the mean value $69.3^{\circ}$. Unlike the inferior facet angle with respect to the frontal plane with large range, minimum value $32.3^{\circ}$ and maximum $51.4^{\circ}$. When compared to the previous studies, the superior facet angle measurement is the most similar to study performed by $\mathrm{Xu}$.

Spinal canal was measured for three linear parameters; width and superior and inferior depth (Table 6). For definition of spinal canal depth, two parameters were established as the superior inlet and inferior outlet antero-posterior diameters were significantly different. The inferior outlet depth was always smaller than the superior outlet depth because of the vertebral body enlargement at the inferior area (Figure 7).

\begin{tabular}{|l|l|l|l|}
\hline Spinal canal & $\begin{array}{l}\text { Spinal canal } \\
\text { width }\end{array}$ & $\begin{array}{l}\text { Spinal canal } \\
\text { superior depth }\end{array}$ & $\begin{array}{l}\text { Spinal canal } \\
\text { inferior depth }\end{array}$ \\
\cline { 2 - 4 } & SCW & SCDs & SCDi \\
\hline Mean & 24.4 & 18.0 & 16.2 \\
\hline SD & 1.0 & 1.9 & 1.6 \\
\hline Maximum & 25.4 & 20.1 & 18.0 \\
\hline Minimum & 23.0 & 14.6 & 13.2 \\
\hline
\end{tabular}

Table 6: Parameters of the spinal canal. 
Page 6 of 7

The spinal canal width measurement, mean value $24.4 \mathrm{~mm}$, follows results of the study done by Sengul which is $24.7 \mathrm{~mm}$ [15]. Although in case of spinal canal depth, Sengul measured values considerably greater than other studies. However, Singla, Gosavi and Xu presented the parameters very similar to the present study $[18,26,27]$.

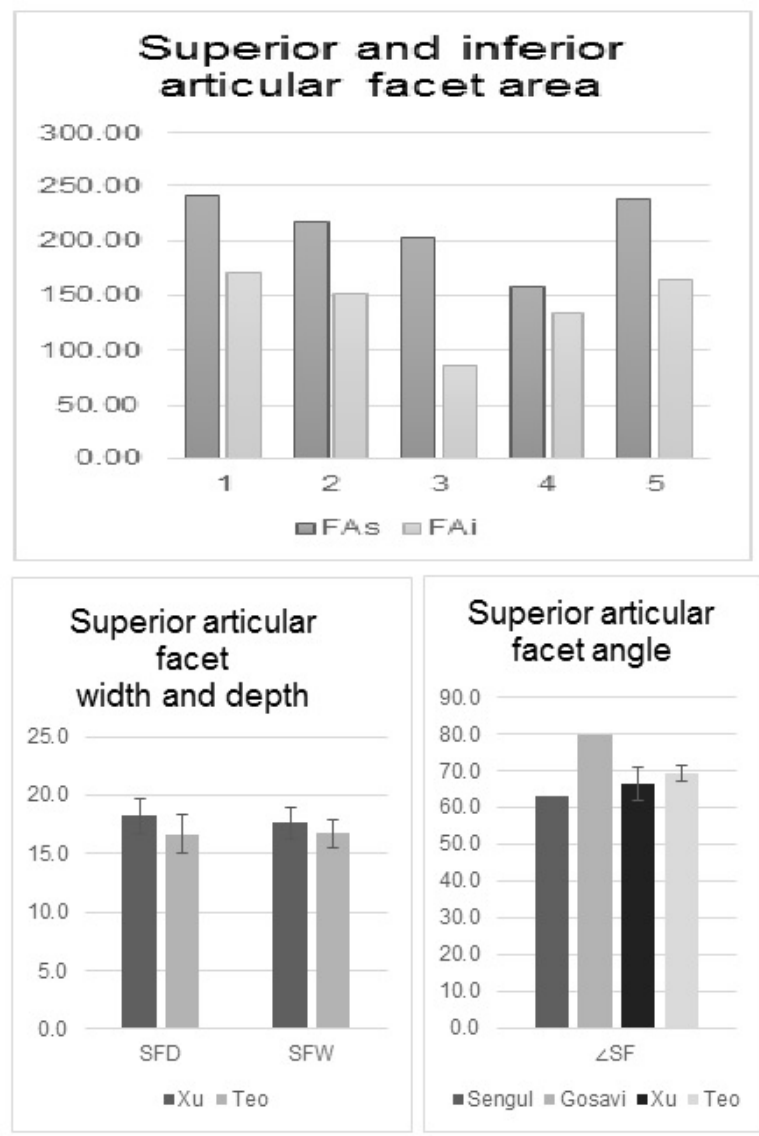

Figure 6: The comparison of superior and articular facet is for five specimens and the comparison of superior facet width, depth and angle to the previous studies.

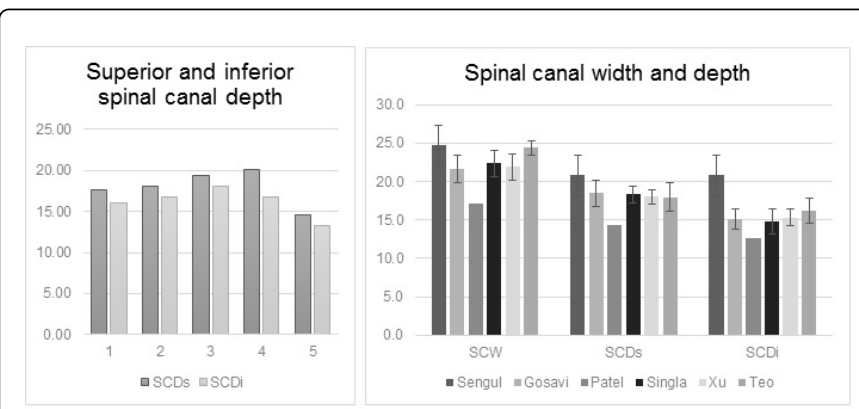

Figure 7: Spinal canal superior and inferior depth comparison. The compariosn of spinal canal parameters to the rpevious studies.

\section{Conclusion}

In the present study, five Caucasian male specimens were examined to assess the parameters of vertebral body, dens, spinal canal and articular facets of the axis vertebra. Linear, angular and area parameters were obtained. Dimensions were measured on threedimensional model reconstructed from CT scans which provide high accuracy. The technique also allowed a simple measurement of area either on the cutting plane or on the surface of the bone. Although area parameters provide more relevant values for further clinical investigation, no previous studies evaluating the area parameters were found.

The results and their further comparison showed several significant features. Vertebral body anterior height $(26.2 \mathrm{~mm})$ was found to be bigger than the posterior height $(21.4 \mathrm{~mm})$, this was also supported by the results of previous studies. Vertebral body width $(18.2 \mathrm{~mm})$ was observed to be larger than the vertebral body depth $(17.4 \mathrm{~mm})$, although for some specimens these parameters were rather similar. Unlike the previous studies, the dens axis was assessed by parameters located at the upper part and at the root of the dens. Although the mean value of dens superior width $(11.5 \mathrm{~mm})$ was bigger than the one measured at the root $(11.2 \mathrm{~mm})$, the upper values were not always bigger. The present study determined mean value of dens axis height to be $17.8 \mathrm{~mm}$ which is significantly greater value compared to the previous studies. There were large variations in dens sagittal and vertical angle, as previously reported by Doherty [24]. Although the mean values of the sagittal angle $\left(12.7^{\circ}\right)$ compared to studies done by Doherty and Singla were similar. Furthermore, results showed that superior facet area $\left(211.1 \mathrm{~mm}^{2}\right)$ was significantly larger than inferior facet area $\left(141.16 \mathrm{~mm}^{2}\right)$. Because of the vertebral body enlargement in the inferior part of vertebra, the spinal canal superior depth $(18.0 \mathrm{~mm})$ was observed to be bigger than its inferior depth $(16.2 \mathrm{~mm})$.

The data presented in the study are meant to contribute to creation of the precise database of vertebral dimensions of Caucasian population. The results can serve as reference values used for diagnosis of various clinical conditions. Moreover, measured dimensions can be used in modelling of the axis for improved implant or surgical instrumentation design and related FEM analysis. They may also be helpful for preclinical planning to avoid or minimize surgical complication such as vertebral artery injuries or damage to other vital structures.

\section{Acknowledgements}

This research is supported by School of Mechanical and Aerospace Engineering of Nanyang Technological University, Singapore [Rekindle Seed Grant].

\section{References}

1. Mayer F, Börm W, Thomé C (2008) Degenerative cervical spinal stenosis. Dtsch Arztebl Int 105: 366-372.

2. Clark CR, White AA (1985) Fractures of the dens: A multicentre study. J Bone Joint Surg Am 56: 1340-1348.

3. Ochoa G (2005) Surgical management of odontoid fractures. Injury 36 : 54-64.

4. Madawi AA, Case ATH, Solanki GA, Tuite G, Veres R, et al. (1997) Radiological and anatomical evaluation of the atlantoaxial transarticular screw fixation technique. J Neurosurg 86: 961-68.

5. Wrigth NM, Lauryssen C (1998) Vertebral artery injury in C1-2 transarticular screw fixation: Results of a survey of the AANS/CNS 
Citation: Teo EC, Haiblikova S, Winkelstein B, Welch W, Holsgrove T, et al. (2017) Morphometric Analysis of Human Second Cervical Vertebrae (Axis). J Spine 6: 399. doi:10.4172/2165-7939.1000399

Page 7 of 7

section on disorders of the spine and peripheral nerves. J Neurosurg 88 634-640.

6. Gupta S, Goel A (2000) Quantitative anatomy of the lateral masses of the atlas and axis vertebrae. Neurol India 48: 120-125.

7. Tan SH, Teo EC, Chua HC (2004) Quantitative three-dimensional anatomy of cervical, thoracic and lumbar vertebrae of Chinese Singaporeans. Eur Spine J 13: 137-146.

8. Yusof MI, Ming LK, Abdullah MS (2007) Computed tomographic measurement of cervical pedicles for transpedicular fixation in a Malay population. J Orthop Surg 15: 187-190.

9. Chen C, Ruan D, Wu C, Wu W, Sun P, et al. (2013) CT morphometric analysis to determine the anatomical basis for the use of transpedicular screws during reconstruction and fixations of anterior cervical vertebrae. PLoS ONE 8: e81159.

10. Heller JG, Alson MD, Schaffler MB, Garfin SR (1992) Quantitative internal dens morphology. Spine 17: 861-866.

11. Naderi S, Arman C, Guvencer M, Korman E, Senoglu M, et al. (2006) Morphometric analysis of the $\mathrm{C} 2$ body and the odontoid process. Turkish Neurosurgery 16: 14-18.

12. Schaffler MB, Alson MD, Heller JG, Garfin SR (1992) Morphology of the dens. A quantitative study. Spine 17: 738-743.

13. Nucci RC, Seigal S, Merola AA, Gorup J, Mroczek KJ, et al. (1995) Computed tomographic evaluation of the normal adult odontoid. Implications for internal fixation. Spine 20: 264-270.

14. Gupta SK, Roy RC, Srivastava A (1982) Sagittal diameter of the cervical canal in normal Indian adults. Clin Radiol 33: 681-685.

15. Sengul G, Kadioglu HH (2006) Morphometric anatomy of the atlas and axis vertebrae. Turkish Neurosurgery 16: 69-76.

16. Evangelopoulos DS, Kontovazenitis P, Kouris S, Zlatidou X, Benneker LM, et al. (2012) Computerized tomographic morphometric analysis of the cervical spine. The Open Orthopaedics Journal 6: 250-254.

17. Kathole MA, Joshi RA, Herekar NG, Jadhav SS (2012) Dimensions of cervical spinal canal and vertebrae and their relevance in clinical practice.
International Journal of Recent Trends in Science and Technology 3: 54-58.

18. Xu R, Nadaud MC, Ebraheim NA, Yeasting RA (1995) Morphology of the second cervical vertebra and the posterior projection of the $\mathrm{C} 2$ pedicle axis. Spine 20: 259-263.

19. Karaikovic EE, Daubs MD, Madsen RW, Gaines RW Jr (1997) Morphologic characteristics of human cervical pedicles. Spine 22: 493-500.

20. Lu J, Ebraheim NA, Yang H, Heck BE, Yeasting RA (1998) Anatomic considerations of anterior transarticular screw fixation for atlantoaxial instability. Spine 23: 1229-1236.

21. Panjabi MM, Shin EK, Chne NC, Wang JL (2000) Internal morphology of human cervical pedicles. Spine 25: 1197-1205.

22. Kayalioglu G, Erturk M, Varol T, Cezayirli E (2007) Morphometry of the cervical pedicles as a guide for transpedicular screw fixation. Neuol Med Chir 47: 102-108.

23. Sharma RM, Pruthi N, Pandey P, Dawn R, Ravindranath Y, et al. (2005) Morphometric and radiological assessments of dimensions of Axis in dry vertebrae: A study in Indian population. Indian J Orthop 49: 583-588.

24. Doherty BJ, Heggeness MH (1995) Quantitative anatomy of the second cervical vertebra. Spine 20: 513-517.

25. Gosavi S, Swamy V (2012) Morphometric study of the axis vertebra. Eur J Anat 16: 98-103.

26. Parashar R, Chauhan S, Saxena D, Meena SL (2014) A morphometric study of atlas and axis vertebrae in Rajasthan population. J of Evolution of Med and Dent Sci 3: 15497-15506.

27. Singla M, Goel P, Ansari MS, Ravi KS, Khare S (2015) Morphometric analysis of axis and its clinical significance - An anatomical study of Indian human axis vertebrae. J Clin Diagn Res 9: 4-9.

28. Teo EC, Holsgrove T, Haiblikove S (2017) 3D morphometric analysis of human vertebrae C3-T3 using CT images reconstruction. J Spine 6: 391. 